\title{
The South African military and peacekeeping: Reflections on conditions, capacity-building and prospects
}

Theo Neethling ${ }^{\bullet}$

\section{Introduction}

Since the advent of a new dispensation in South Africa, expectations in Africa and elsewhere have steadily grown regarding South Africa's potential role as a peacekeeper in African conflicts. In fact, South Africa has been identified by many observers as the one state able to ensure effective peacekeeping on the African continent. On paper, South Africa's military capabilities appear impressive in terms of African standards. However, in reality there are current impediments to a major role for the South African military in Africa, of which the delicacy of the ongoing transformation process of the South African National Defence Force (SANDF) and financial constraints are significant. Moreover, it would seem that South Africa has thus far preferred the role of diplomatic peacemaker to that of forceful peacekeeper.

Notwithstanding the above, the SANDF has already started to play a political-military role in the security requirements of Southern Africa and even further afield. ${ }^{1}$ From an international perspective, the clear signal being sent to African countries is that they will have to shoulder an increasing responsibility in the conduct of peace missions on the continent. In fact, the traditionally troop-contributing nations have shown great reluctance in recent years to assume the financial and especially military responsibilities associated with peace missions in Africa. To this end, expectations that South Africa will play a leading role in African peacekeeping requirements have been strongly influenced by international efforts to build "indigenous" peacekeeping capacities on the continent.

Being committed to regional peace and security, and to the strengthening of regional security arrangements, the South African government has embarked upon a process of planning for eventualities as regards peace missions. ${ }^{2}$ Against this background the White Paper on South African Participation in International Peace Missions (hereafter White Paper) was approved by Cabinet on 21 October 1998. The White Paper is possibly the most important foreign policy document yet to pass Cabinet, since it forced the South African government to outline its national interests and how these interfaced with its philosophy on conflict resolution and its general approach towards Africa. ${ }^{3}$ This document sets out a proposed policy on South African participation in peace missions and represents the culmination of an interactive process which incorporated the views of representatives of the Department of Foreign Affairs, the Department of Defence (DoD), various other government departments, members of the academic community and civil society. In addition, the SANDF - which will play a prominent role in future peace missions where a military role will be required - is in the process of taking tangible steps towards creating a capacity to assist in preventing or managing

- Centre for Military Studies (Gauteng Branch), University of Stellenbosch

I Since the presentation of this paper South Africa has started to play a limited role in two international peace missions in Africa. These are the United Nations Mission in Ethiopia and Eritrea and the United Nations Organisation Mission in the Democratic Republic of Congo.

2 The notion 'peace mission' is used as a generic term to include all political, diplomatic and military activities related to multinational endeavours to prevent or settle disputes in terms of the UN Charter.

3 J Cilliers. "An emerging South African foreign policy identity?," ISS Papers, Paper 39, April 1999, p.10. 


\section{Neethling}

African conflicts and in alleviating the human suffering caused by such conflicts. One of the most practical steps is to enhance its capability through the training of personnel. At the same time, some analysts argue that South Africa is entering the peace support domain at a time when the world seems to accept that the African environment is "cowboy country", and that major challenges will face the South African military in a tough neighbourhood. ${ }^{4}$

The aim of this paper is to provide a brief overview of the current policy framework and capacity-building initiatives of the SANDF for participation in peace missions. In addition, it reflects on some prospects and challenges facing South Africa in this regard.

\section{Defining peace missions}

Throughout the mid-1990s, a seemingly confusing array of concepts and terms was used regarding the scope and meaning of peace missions. Terms such as "peacekeeping operations", "peace operations", "peace support operations", "peace missions" and others were used interchangeably to denote the overarching spectrum of activities related to involvement aimed at settling international disputes in terms of Chapters VI, VII and VIII of the UN Charter. A very popular term in common use was that of "peacekeeping" as a convenient umbrella term to describe anything from preventive diplomacy to peace enforcement. ${ }^{5}$ The DoD preferred the term "peace support operations" in its policy documents, such as the White Paper on Defence and the Defence Review.

However, some role-players began pointing out that although there was general consensus that all measures aimed at conflict prevention, management and resolution were in essence political/diplomatic activities (with the military as one of the role-players), the word "operation" inevitably created the perception of a military activity. Therefore, it was suggested that the term "peace mission" be used as an appropriate collective and overarching term to describe activities aimed at preventing or settling international disputes in terms of the UN Charter. The idea was to have a term that would ensure the necessary emphasis on the political/diplomatic nature of the activity. ${ }^{6}$ Accordingly, the term "peace mission" is described in the White Paper as an appropriate generic term to include "preventive diplomacy", "peace making", "peacekeeping", "peace enforcement" and "peace building". The White Paper also suggests that the term "peace support operations" be used to refer to all military activities in support of a peace mission. ${ }^{?}$

\section{Peace missions and national interests}

The government's position regarding involvement in peace missions in the past years was inter alia problematised by the absence of a fully 'fleshed out' definition of South African national interests within which such participation could be framed (although the key elements of such interests - sovereignty, safety and the well-being of the citizenry - were alluded to in various national policy documents). Furthermore, some of the key overarching policy sectors (foreign policy and national

M Malan, "Peacekeeping in Africa", in South African Yearbook of International Affairs, Johannesburg: South African Institute of International Affairs 1999, p.279.

B Rossouw, "A South African perspective on the place of peace support operations within broader peace missions", African Security Review, vol 7, no 1, 1998, pp.36-37.

Ibid, p.38.

White Paper on South African Participation in International Peace Missions. (Approved by Cabinet on 21 October 1998), p.8. 
security for instance) were either underdeveloped in the case of former or non-existent in the case of the latter; making it difficult to deduce national interests from the existing policy environment. ${ }^{8}$

A position was finally adopted according to which, as stated in the White Paper, South Africa's emerging national interests are based on the values enshrined in the Constitution and other policy documents which are concerned with the security of the state and its citizens, the promotion of the social and economic well-being of the citizenry, the encouragement of global peace and stability, and participation in the process of ensuring regional peace and stability.

With this framework as a background, the link between South Africa's national interests and its participation in peace missions is made by stating that it is in the South African national interest to assist peoples who suffer from famine, political repression, natural disasters and the scourge of violent conflict. The country may thus provide civilian assistance and contribute armed forces to international efforts when properly authorised. It is also stated that South African foreign policy makes Africa the prime focus of future engagements. This means that South Africa has an obvious interest in preserving regional peace and stability in order to promote trade and development and to avoid the spillover effects of conflicts in the neigbourhood. ${ }^{9}$

Thus there is a realisation that problems relating to political conflict are not confined within the national borders. They also impact negatively on neighbouring states in the form of a range of non-military threats: environmental destruction; the spread of disease; the burden of refugees; and cross-border trafficking in drugs, stolen goods and small arms. ${ }^{10}$ In this regard the DoD realises that conflicts in southern and central Africa, whether inter- or intrastatal, can be disastrous - not only on the regional community of which South Africa forms an integral part, but also on South Africa itself. ${ }^{11}$

\section{Conditions for participation}

It is interesting to note that the initial draft of the White Paper (dated 25 July 1997) sought to include the obtaining of a mandate from both the Organisation of African Unity (OAU) and Southern African Development Community (SADC) if a peace mission in Southern Africa was to be conducted. (This had been motivated on the basis of the pronouncement of the White Paper on Defence and the Defence Review that operations in Southern Africa should be sanctioned by the SADC and that operations in Africa should be sanctioned by the OAU.) However, concern was expressed by certain role-players that the time-consuming nature of securing endorsement for peace missions from either the OAU and/or SADC could well militate against South Africa being able to respond to crises at all. ${ }^{12}$ Therefore, the White Paper now provides for participation that would occur if missions were authorised by the UN and agreed to between the UN, regional bodies (where applicable), the host country, the conflicting parties, and contributing countries. It is also proclaimed that participation should be linked to concrete political solutions and should not be seen as an end in

\footnotetext{
R Williams, "Peace support operations", in South African Yearbook of International Affairs, Johannesburg: South African Institute of International Affairs 1997, p.240.

White Paper on South African Participation in International Peace Missions, op cit, pp.20-21.

South African Defence Review. (Approved by Parliament, April 1998), p 18.

P Steyn, "South Africa and peace support operations: limitations, options and challenges". Paper presented at a conference, Contemporary Peace Support Operations, organised by the Institute for Security Studies, Pretoria, 5 November 1997, p.9.

12 R Williams, "Challenges for South and Southern Africa: towards non-consensual peace missions?". Paper presented at a conference, From peacekeeping to complex emergencies: peace support missions in Africa, organised by the Institute for Security Studies and the Institute of International Affairs, Johannesburg, 25 March 1999, p.12.
} 


\section{Neethling}

itself. South African participation in peace missions should furthermore occur when there is a clear threat and/or breach of international peace and security and/or a disaster of humanitarian proportions and/or endemic causes of conflict that, unless addressed, may cause long-term instability.

The drafters of the White Paper also addressed the importance of securing a domestic mandate and a proper budget for participation in peace missions. It is clearly provided for certain stakeholders - the Executive and the Legislature - to be involved in securing domestic approval for participation in a peace mission. ${ }^{13}$ However, the challenge in this regard will be to balance the necessity of popular domestic support with the need for decisive action when faced with a crisis where the security of people is imperilled.

The responsibilities of the relevant government departments are also outlined in the White Paper. Other sections of the document deal with factors, which need to be considered prior to participation, or principles that must be met before resources are deployed in support of a particular peace mission. These include the need for clear entry and exit criteria, the principle of volunteerism ${ }^{14}$ for participation in peace missions, co-operation with neighbouring states, and an outline of the procedures for deployment in peace missions. The clarification of the Status of Forces Agreement (signed between the UN and the country of deployment/countries concerned to ensure the legality of a peace force) and the Rules of Engagement (which govern the use of force on the part of a peace mission) are also specifically addressed. ${ }^{15}$

\section{The challenge of peacebuilding}

Peacebuilding is critical in the aftermath of a conflict. The staging of free and fair elections normally marks the transition of the post-conflict state, but this has little chance to succeed in the long-term unless emphasis is placed on the essentials of efficient and effective governance. These include adherence to the rule of law; competent and fair judiciaries; effective policing and a criminal justice system; and a professional public service. The White Paper places a strong emphasis on peace building and maintains that peace missions should be viewed as long-term endeavours, and not merely as short-term engagements. Peace building is therefore outlined as: the inculcation of respect for human rights and political pluralism; the accommodation of diversity; building the capacity of state and civil institutions; and promoting economic growth and equity. It is claimed that these measures are the most effective means of preventing crises, and are therefore as much pre-crisis as post-crisis priorities. ${ }^{16}$

Peacebuilding is mainly a diplomatic/developmental process, although it is likely that the South African military will be requested to support such processes in the conducting of future peace missions. Whilst the White Paper is laudable for its intentions regarding peacebuilding, some analysts argue that it is difficult to comprehend how South Africa, a country which is afflicted by high levels of poverty and unemployment, can meaningfully address this malaise in other African states. ${ }^{17}$ It is argued that the government will have to clarify both the policy and resource implications of its intended commitment to peace building in more detail. ${ }^{18}$ Thus it is clear that the normative

13 White Paper on South African Participation in International Peace Missions, op cit, p.27.

14 This relates to the principle of participation by SANDF personnel in peace missions on a voluntary basis.

15 White Paper on South African Participation in International Peace Missions, op cit, pp.27-33.

16 Ibid, p.19.

17 M Malan, "Keeping the peace in Africa: a renaissance role for South Africa", Indicator SA, vol 15, no 2, Winter 1998, p.21.

18 R Williams, 1999, op cit, p.14. 
orientation of the White Paper regarding peace building is not beyond challenge. Also, in the context of current realties in Africa - where peacekeeping is often concerned with enforcing peace in impoverished, weak and collapsing or collapsed states - it can be argued that this point has more relevance for the countries of the European community than those on the African continent. In fact, it can be stated that concerns regarding post-conflict peacebuilding are largely peripheral to the debate on the future of African peacekeeping. Still, Africans must carefully take cognisance of international developments concerning the promotion of development and democratisation through peacebuilding programmes.

\section{Level and size of contribution}

As a rule, the UN Security Council decides on the establishment of UN peace missions. Normally the UN Secretariat makes an initial assessment of the task and consults several states or even regional organisations about possible contributions. The level and size of contributions will obviously depend largely on the demands made by the UN.

A South African contribution to a peace mission would obviously have to be meaningful and carefully considered. In this regard, the White Paper states that in principle, the level and size of a South African contribution to any particular peace mission will depend on how closely the mission relates to national interests and the type of demand that exists for contribution. ${ }^{19}$

It must also be understood that the primary function of the SANDF is to defend South Africa against external military aggression. In terms of the current mandate of the SANDF, participation in peace missions is a secondary function. Accordingly, South Africa shares the view of many of its neighbouring countries that the creation of a standing peace force is not required or feasible. The country is therefore likely to engage in peace missions on an ad hoc basis. ${ }^{20}$ Furthermore, as far as force design is concerned and in terms of the mandate of the military, the SANDF will not create special structures for such operations, but will rather provide for them within the primary structure. In accordance with current policy, two motorised infantry battalion groups of the SA Army's Rapid Deployment Ground Force should be prepared for peacekeeping undertakings on a relay basis, while the capabilities of its mechanised and parachute forces should be prepared for deployment in peaceenforcement situations.

The SA Air Force, SA Navy and SA Military Health Service will similarly not provide for dedicated force components for peace missions, but must ensure that the components that may be deployed in such operations are equipped and trained appropriately. ${ }^{21}$ The expected role of the SA Air Force will typically include: the transportation of large quantities of goods and resources into and out of a region; rapidly deploying forces or transporting fact-finding missions; evacuating wounded personnel to medical facilities; surveillance; reconnaissance; communications and search and rescue operations. The anticipated role of the SA Navy will mainly be: to patrol international waterways; to monitor cease-fire agreements; to provide intelligence, logistical support, communications and medical evacuation, while its amphibious forces could be called upon as an immediate reaction force. The SA Military Health Service is expected to render operational medical support to SANDF forces deployed as part of peace efforts and/or even an entire peace mission. ${ }^{22}$

19 White Paper on South African Participation in International Peace Missions, op cit, p.25.

20 Defence Review. (As approved by Parliament April 1998), Department of Defence: 1 Military Printing Regiment, p.20.

$21 \quad$ Ibid, p.26.

22 See Joint Warfare Manual: Peace Support Operations GWU 106 Part 2 


\section{Neethling}

It must be noted that the SA Army especially will play an important role in peace missions. The very nature of such operations requires that the bulk of operational personnel be infantry. Normally, an army contribution to a peace mission typically includes: infantry contingents (to perform protection and escort duties); engineers (demolition, demining, construction, water provision, etc.); signals/communication contingents; armour (to ensure effective traffic control and vehicle control points and to play a more offensive role in peace enforcement); and military police personnel (to ensure discipline within the armed forces in question).

The government is aware of the challenge that the SANDF must formalise its minimum potential contribution to international peace missions through an appropriate readiness system, however difficult this may be at the current state of force transformation. ${ }^{23}$ This could best be done by creating a pool of high-quality personnel who could be made available for participation in peace missions through the existing system of UN standby arrangements (which has been established with a view to determining a precise understanding of the forces and other capabilities that member states have available for rapid deployment). In this context, the White Paper makes mention of the UN system of standby agreements. ${ }^{24}$ Given the fact that a number of African countries (such as Botswana, Zambia, and Zimbabwe in Southern Africa) have subscribed to the UN system, it would make sense for South Africa to give a signal of positive intent by committing itself to this system. ${ }^{25}$ This is likely to happen after the country has made an audit of existing military, policing and civilian experience in the field of peacekeeping. ${ }^{26}$

As far as the positioning of the South African military is concerned, the DoD has determined that participation in peace missions will not be limited to the deployment of troops. It could also take the form of providing equipment, logistical support, humanitarian aid, engineering services, communications systems and medical personnel and facilities. ${ }^{27}$ In fact, the SANDF has already provided logistic, airlift and specialist support for peace missions since 1990. For example, the SANDF provided logistic and electoral assistance in Angola and Mozambique. It has also provided humanitarian assistance to Burundi and has assisted the government of Angola with the training of demining teams. ${ }^{28}$ The White Paper also deals with unarmed UN military observers found in contemporary peace missions. ${ }^{29}$ In this regard, it would seem that South Africa has a pool of military officers in the rank from captain and upwards, who are ideally suited for service as military observers. $^{30}$

\section{Training for peace}

Needless to say, peace missions generally involve many challenges and potential problems. Professional armed forces, commanded by professional officers, properly trained for their primary

\footnotetext{
23 The White Paper also places a great deal of emphasis on the civilian component of peace missions as a cardinal aspect of the "new peacekeeping partnership".

24 White Paper on South African Participation in International Peace Missions, op cit, p.21.

$25 \quad$ M Malan, op cit, p.23.

26 W Nhlapo, "South Africa and peacekeeping: a look to the future". Paper presented at a conference, From peacekeeping to complex emergencies: peace support missions in Africa, organised by the Institute for Security Studies and the South African Institute of International Affairs, Johannesburg, 25 March 1999, p.3.

27 Defence Review, op cit, p.23.

28 White Paper on South African Participation in International Peace Missions, op cit, p.24.

29 Ibid, p.13,

$30 \quad$ M Malan, op cit, p.23
} 
mission and well disciplined, are the only forces to be deployed for peace support operations. ${ }^{31}$ In Africa, peace initiatives pose an even greater challenge than in other parts of the international community. It is commonly known that in Rwanda, for example, a three-year UN 'peacekeeping' operation failed to halt ethnic genocide, which resulted in between 500000 and one million deaths. More recently, the UN peacekeeping effort in Sierra Leone, that was suppose to exemplify the UN's commitment to Africa, suffered a serious setback early in May 2000 when members of the peace force were violently attacked by rebels. This resulted in fatalities on the part of the UN peace force, while the rebels took hostage several hundred peacekeepers. Immediately, the British Broadcasting Corporation (BBC) stated that peacekeeping around the world had not had a happy recent history and that it had been a disaster in Africa. ${ }^{32}$ UN Secretary-General, Kofi Annan, stated in his reaction "...that the international community and the Western countries were not ready to go to Rwanda" and "... after Sierra Leone, I think there's going to be little encouragement for any of them to get involved in operations in Africa". ${ }^{33}$ Even in the case of African contributions to peacekeeping efforts it has been reported that Kenya's participation hangs in the balance after the killing of seven Kenyan soldiers and the capture and wounding of several others in Sierra Leone. ${ }^{34}$

The SANDF believes that when it does contribute troops to international peace missions, its forces must be equipped and trained to the highest standards. ${ }^{35}$ Since the undertaking of peace missions is a daunting challenge under any circumstances, proper standards of training and the quality and professionalism of soldiers can hardly be overemphasised. As peace missions also require a different approach than that required for war, a train-up is desirable, if not imperative. The DoD has therefore indicated its intention in policy documents to address the skills, attitudes and expectations of SANDF personnel through thorough training prior to deployment. It also intends to brief its personnel on the political, cultural, linguistic and geographic features of the country of deployment, and to ensure that they know and understand the Rules of Engagement.

According to current policy, training is to be based on typical peace support tasks. These will include: cease-fire monitoring and maintenance; check-point operations; medical assistance to the civilian population; crowd control at food distribution points; the apprehension of criminals and fulfilling certain legal responsibilities in conflict situations. In addition, training will focus on mediation, negotiation, and consensus-building skills, while the importance of impartiality, patience, tolerance and political sensitivity will similarly be addressed. Training is also to be undertaken jointly with the forces of countries with which South Africa is likely to be involved in peace missions.

As with many other countries, the development of training for peace missions in South Africa focuses particularly on the Army. To this end, the SA Army, tasked by the Chief of Operations, has produced a draft Joint Warfare Manual: Peace Support Operations. This manual deals with a wide range of aspects, namely the fundamentals of peace missions, multinational co-operation, strategic levels, operational levels, command responsibilities, legal considerations and other matters. ${ }^{37}$ V Gamba and J Potgieter, "Multifunctional peace support operations: evolution and challenges", ISS Monograph Series, no 8, 1997, p.76.

32 BBC, "UN failing in Africa", http://news.bbc.co.uk/hi/english/world/africa/newsid_737000/737053.stm", 8 May 2000.

33 N Onishi, “Attacks could cause U.N. to again shy from region”, New York Times, 5 May 2000, p.1. Anon, "Kenyans angry over deaths of peacekeeper soldiers", Pretoria News, 31 May 2000, p.13. White Paper on South African Participation in International Peace Missions, op cit, p.24.

Defence Review, op cit, p.26.

See South African Army Joint Warfare Manual: Peace Support Operations GWU 106 Part 2.
} 


\section{Neethling}

In order to properly prepare for peace missions, the SANDF has already begun to address the notion of peace missions and the anticipated role of the South African military in study programmes and exercises at various SANDF training institutions. As far as officer training is concerned, the aim is to provide officers with a theoretical and practical orientation towards the doctrine, planning and command and control of peace missions. Selected senior officers and personnel have already received peacekeeping training abroad, and have visited Bosnia and other places to study NATO peacekeeping activities. ${ }^{38}$ Peace support training was likewise started at the lowest level for all new intakes. Other units were also identified for such training. The SA Army Battle School is specifically attending to training programmes and exercises, especially as regards the tactical level. The SA Army College, with its function of research and development, also attends to peace support exercises in both the Junior Command and Staff Duties Course and the Senior Command and Staff Duties Course. The aim is to equip officers with the necessary knowledge, skills and attitudes that will enable them to execute the planning and control of peace missions. The SA Army College is furthermore in liaison with other staff colleges in Africa with a view to promoting a greater degree of regional co-operation in terms of peacekeeping training at command and staff level. ${ }^{39}$

In view of the preceding, the senior officer training programmes of the SA Army College is of special interest. A point in case is a peacekeeping exercise, dubbed Exercise PEGASUS, held at the SA Army College since 1997. This exercise is organised by the staff of the Senior Command and Staff Duties Course with a view to providing senior officers of the SANDF with a theoretical and practical orientation on the doctrine, planning and command and control of peace missions at the strategic, operational and tactical levels. ${ }^{40}$

As the peace missions module on SANDF Senior and Command and Staff Duties Courses, Exercise PEGASUS is annually presented by the SA Army College to between 150 and 200 officers from all Arms of the Service of the SANDF, civilian members of the DoD, the SA Police Service, the Department of Foreign Affairs and various representatives from other defence forces in Africa and further afield. Training is supported by the UN High Commissioner for Refugees, the UN Development Programme and local research institutions. ${ }^{41}$ The SANDF is therefore in the process of aligning its forces with a view to assuming the task of peace missions.

\section{Multinational capacity building}

It is envisaged in the White Paper that continued regional co-operation in the realm of preparation might eventually lead to a joint and combined SADC contribution to a peace mission of the UN or even the OAU. In this context, the armed forces of eight member states of SADC (including a contingent from the SANDF) participated in Exercise Blue Hungwe, a multinational peace support exercise held in April 1997 in the Nyanga area in Zimbabwe. The exercise was assisted and facilitated by British military experts. Blue Hungwe was followed by Exercise Blue Crane held in April 1999 in South Africa at the grounds of the SA Army Battle School in the Northern Cape Province. The latter involved approximately 4000 defence force members from Angola, Botswana, Lesotho, Malawi, Mozambique, Namibia, South Africa, Swaziland, Tanzania, Zambia and

\footnotetext{
38 G Shelton, "Time for SA to go peacekeeping", The Star, 2 September 1997, p. 12.

39 Ibid.

40 Interview with Lieutenant-Colonel Johan van der Walt, Senior Command and Staff Duties Branch, South African Army College, Thaba Tshwane, 4 November 1997.

$41 \quad$ SA Army College, Exercise Pegasus: Peace Support Operations, September 1998, p.2-1.
} 
Zimbabwe, ${ }^{42}$ and was clearly the biggest peacekeeping exercise ever conducted on African soil. The SANDF played a major role in Exercise Blue Crane. Not only did the SANDF play host to the event, it also provided the exercise director and control staff during the exercise. ${ }^{43}$

The broad aim of Exercise Blue Crane was to enhance the peacekeeping capacity in Southern African and to improve the ability of SADC member states to work together. More specifically, the objectives of the exercise were as follows: ${ }^{44}$

- To exercise regional and multinational command and control during peace missions at all applicable levels.

- To exercise the application of the doctrine and principles for peace support operations as laid down by the UN and the OAU.

- $\quad$ To practice regional deployment by road, rail, air and sea.

- $\quad$ To exercise basic skills required for peace missions at section, platoon, company and battalion levels, namely Rules of Engagement, patrolling, incident reaction, convoys and convoy protection, base and key point security, control of areas of responsibility, observation and gathering of military information, mine and booby trap awareness, mine clearing and helicopter landing.

- $\quad$ To exercise support to humanitarian relief operations with reference to -

- assistance with maintaining the local infrastructure;

- developing of civil-military relations;

- $\quad$ practice in the procedures for the handling of refugees, prisoners, returnees and displaced persons; and

- practice in the handling of casualties.

- To exercise the planning and employment of air assets.

- $\quad$ To exercise naval support during peace missions.

- To practice the application of the Law of Armed Conflict during peace missions.

- To practice logistical support within a multinational force.

- To exercise a multinational formation level headquarters in the command of peace missions.

- To generate regional Standard Operating Procedures.

- To train all ranks in the handling of the media.

- To practice the monitoring of demilitarised zones and the movements of opposing forces.

- To practice the establishment of freedom of movement and the promotion of violence cessation.

\footnotetext{
42 The Democratic Republic of the Congo and the Seychelles did not take part in the exercise.

43 Department of Defence Bulletin, "Exercise Blue Crane", 31 March 1999, p.1.

44 Exercise Blue Crane South Africa 7-30 April 1999, SADC Info Booklet for Military Attachés, pp.5-6.
} 
The above-mentioned exercises are of particular significance to Southern African countries in terms of current efforts to enhance the all-round capacity of SADC military forces for participation in peace missions. The forces of Southern Africa practically proved that they can train and operate together and, in fact, came closer to taking up peace support responsibilities on the African continent. The SANDF officer who took charge of Exercise Blue Crane, Major-General André Bestbier, stated in an interview that the co-operation among the various forces was "a wonderful experience". He also mentioned that the initial skepticism on the part of foreign observers that SADC countries would not be able to put together such an exercise was dispelled. ${ }^{45}$

Based on the results of Exercise Blue Crane, an in-depth analysis of SADC's existing ability and capacity to participate in peace missions was carried out. The outcome of this helped to determine future planning for capacity building within SADC as a grouping, as well as individual countries. $^{46}$

\section{Challenges and future prospects}

There can be no doubt that South Africa will remain subject to multiple pressures to 'do something' to help put an end to fighting in conflict-stricken African states. In fact, the Secretary General of the OAU, Mr Salim Ahmed Salim, made it clear during a visit to South Africa in December 1998 that he had been disappointed by South Africa's reluctance to play a more active role in conflict resolution in Africa. ${ }^{47}$ Since the creation of the SANDF in 1994, the South African position may be described as cautious when it comes to committing forces to peace missions. Firstly, the practical difficulties of integrating seven formerly adversarial forces (as a result of the political process) and of training them for peace missions have elicited caution on the part of the DoD. ${ }^{48}$ The novelty of such operations is another important aspect upon which the DoD urges caution in the light of the fact that peace support tasks are new to South Africa and the SANDF. ${ }^{49}$ Also, it is commonly know that reduced military spending and a dwindling defence budget have been in the centre of significant budgetary changes in South Africa in the past decade. The SANDF has seen many years of consecutive cuts. Moreover, the situation that the defence budget is presently set at just over 1,5 per cent of the Gross Domestic Product produces the dilemma of a discrepancy between the peacekeeping requirements emanating from national policy and the capability of the SANDF to meet such requirements. $^{50}$ This forms an important part of explanations concerning South Africa's preference in the past years for a role of diplomatic peacemaker to that of military peacekeeper. Given the duration of and the financial implications of peace missions on the one hand, and the government's commitment to fiscal and monetary discipline and the reorientation of its economy on the other, the decision-makers is perhaps to be forgiven for their caution when it comes to committing troops to peace missions. ${ }^{51}$

H Pienaar, "War games lay ground rules for peace force", The Star, 28 April 1999, p.5.

46. Exercise Blue Crane South Africa 7-30 April 1999, op cit, p.5.

47 M Malan, “' 'Renaissance peacekeeping' - a South African solution to conflict in the DRC”, ISS Papers, Paper 37, March 1999, p.3.

$48 \quad$ P Steyn, op cit, p.9.

49 Defence Review, op cit, p.22.

L le Roux, "Defining defence requirements: force design considerations for the South African National Defence Force", African Security Review, vol 8, no 5, 1999, p.63. 
However, the government declared that as a member of the UN, South Africa has the task to assist the world body in fulfilling its peacekeeping task, especially as the country has aspirations to become a permanent member of the Security Council of the UN. ${ }^{52}$ In addition, there is a realisation in South Africa, as in the broad international community, that the movement to a new world order and the reality of international economic interdependence has resulted in a growing awareness that the world forms an integrated unit or "global village". This awareness has had a significant impact on perspectives on national security. This notion is no longer perceived as a rather narrow military one: that of the physical protection of the state against external threats and the maintenance of territorial integrity. In South Africa, the notion of national security has thus been broadened to encompass more than merely achieving an absence of war: it also includes the pursuit of democracy, sustainable economic development and social justice. ${ }^{53}$ Hence, it would appear that South Africa's conundrum is that it must sail between the Scylla of national interest and humanitarian concern, and the Charybdis of financial and military prudence. ${ }^{54}$

Although politicians and policy analysts previously seemed to differ on the extent to which South Africa should become engaged in the region, it would appear that there is general agreement that regional co-operation is essential for ensuring a favourable security environment. It is thus accepted that South Africa could become involved in peace missions in Southern Africa and even further afield. To this end, there seems to be a broad consensus that South Africa has a vested interest in regional peace and security and that the country must carefully and systematically engage in peacekeeping efforts if the country is to acquit itself in a responsible manner. At the same time, certain impediments to its engagement in peace missions remain, and the extent to which the SANDF will be permitted to assist in achieving a greater deal of peace and stability on the African continent in the near future, will have to be determined.

Furthermore, South Africa's involvement in the SADC intervention operation in Lesotho that begun on 22 September 1998 clearly illustrated, in a very practical manner, the factors that need to be considered prior to the deployment of South African troops in a regional operation in the realm of peace and security. Firstly, using the intervention operation in Lesotho as a test case, any future deployment in either a peace mission or an intervention operation will have to consider the following: ${ }^{55}$

- The extent to which all the major role-players within government have been informed and/or involved in both the preparation and planning for the operation.

- The extent to which key members of the legislature are informed of such impending action.

Secondly, for regional deployment it is clear that a range of factors need to be considered. The legal and procedural mandates governing the participation of countries in the region need to be determined. Hence, the extent to which the different national interests of the concerned countries can be co-ordinated and streamlined into common and cohesive strategies will be of critical importance.

\section{South Africa in regional context}

\begin{tabular}{ll}
\hline 52 & W Nhlapo, op cit, p.5. \\
53 & White Paper on Intelligence. WP (H) - October 1994, pp.6-7. \\
54 & P Steyn, op cit, pp.8-9. \\
55 & R Williams, 1999, op cit, p.16. \\
$\begin{array}{l}\text { Scientia Militaria 31(1) } \\
2003\end{array}$
\end{tabular}




\section{Neethling}

South Africa shares a common future with Southern Africa. The South African destiny is inextricably tied to its neighbourhood. By the same token, it should be noted that South Africa's position in Africa and Southern Africa in particular has hitherto been strongly influenced by its own recent history and its relations with neighbouring states. South Africa's reputation for power projection into Southern Africa prior to its transition to democracy in 1994, undoubtedly created suspicion about South Africa's intentions, and the government has to take this into account. By the same token, it can be argued that South Africa's intervention in Lesotho under the auspices of SADC in September 1998 has strengthened or perpetuated negative perceptions in this regard. ${ }^{56}$ The prospect of future involvement in peace missions is thus constrained by the memory of the country's past military involvement in the region and by negative viewpoints as regards regional 'giantism' or supremacy. Hence, South Africa will have to walk a tightrope in its relations with neighbouring countries and in the region. It will have to assume a leadership role as regards certain issues, but will also have to be prepared to follow the lead of other countries on other issues.

Another issue concerns the need for more co-ordination and cohesion in approaches towards the resolution of conflict. Some observers expressed concern about a "militaristic ethos" which has pervaded the conflict resolution strategies adopted by some SADC member states in the Democratic Republic of Congo (DRC) since 1998. Specifically, it has been claimed that the involvement of Zimbabwe and Angola in the conflict has shown little support for conflict resolution (and peace missions) as longer-term, political-diplomatic strategies and attempts to secure lasting peace and stability. It has also been argued that there is a clear disjunction between the foreign policy paradigms of Zimbabwe, Namibia and Angola on the one hand, and those of South Africa, Botswana, Mozambique and Tanzania on the other. ${ }^{57}$ Be that as it may, it can be concluded that ensuring a sound normative and strategic basis for future multinational approaches towards conflict resolution will be dependent on the acceptance of democratisation, state restructuring and policy re-orientation as part of conflict resolution efforts on the continent.

South Africa and the rest of the continent also have to face a harsh reality underlying the UN's involvement in peacekeeping requirements in Africa, namely that Western countries, by and large, are unwilling to become directly involved in the continent. Yet, this does not imply a disregard by Western countries for peacekeeping challenges on the African continent. By providing African countries with peacekeeping training, instruction and equipment, Western states hope to obviate the need for them to intervene militarily in Africa. This is especially evident from programmes driven by the US, France and Britain to develop African peacekeeping capabilities. ${ }^{58}$ In practical terms, this boils down to the use of regional organisations and/or "coalitions of the willing and able" to do peacekeeping with the back-up of external capacity-building initiatives to strengthen African peacekeeping capabilities. The support from Britain and the US to the Economic Community of West African States Monitoring Group (ECOMOG) in Sierra Leone in recent years is a case in point. ${ }^{59}$

In addition, UN Secretary-General Annan indicated that earlier collaboration between the UN and the Economic Community of West African States (ECOWAS) succeeded in helping to restore peace in Liberia. Therefore, he regards this as a case of co-operation that might be applicable to other

\footnotetext{
56

Anon, "French press slams SA's Lesotho fiasco", Pretoria News, 28 September 1998, p.3.

R Williams, 1999, op cit, p.15.

58

EG Berman and KE Sams, "Constructive engagement: Western efforts to develop African peacekeeping", ISS Monograph, no 33, December 1998, p.23; p.30.

J Cilliers, "Regional African peacekeeping capacity - mythical construct or essential tool?". Paper presented at a conference, Building stability in Africa - the challenge for the next millennium, organised by the Institute of Security Studies, Pretoria, 22-24 November 1999, pp.2-3; p.11.
} 
situations as well. As far as the delegation of peacekeeping responsibilities is concerned, the Secretary-General believes that "...the experience in Liberia clearly shows the contribution that can be made by a subregional organisation such as ECOWAS when dealing with so complex a situation, and the key role that the UN can play in support of such efforts. Judgement and caution must be exercised in associating the UN with regional, subregional or multinational efforts but the potential for positive co-operation should continue to be explored". 60 This outlook on African peacekeeping requirements has been echoed in a report by the Security Council in which it was stated that "[i]t was essential to think in terms of partnerships with Africa, with the Organization of African Unity (OAU), regional and sub-regional organizations, civil society and individuals."

By the same token, it must be clear that an important development in the international community at large concerns the trend for regions to accept co-responsibility and to share the burden of policing themselves. Practically speaking, this means a dilution of the central role many hoped that the UN would play in peacekeeping challenges worldwide and in Africa in particular. Basically, this trend concerns an approach to build global security on a strategy of co-option and devolution of responsibility from what remains a relatively weak international system of conflict prevention and management. This development has been sharpened by NATO's intervention in Kosovo. ${ }^{61}$ Also, it can be pointed out that in the case of East Timor, the UN was able to intervene in the conflict with proper force mainly as a result of Australia and New Zealand's swift responses and their commitment to a peacekeeping effort. Moreover, the bulk of the UN peace force in East Timor came from regional contributing nations, such as Australia, New Zealand, Thailand and the Philippines.

The fact that regional role-players are compelled to play an active role in security and peacekeeping is of special significance for South Africa as a regional hegemony. Without South Africa, alliances of the "willing and able" in Southern and Central Africa do not have the practical means to bring security to the region. Analysts generally agree that the success of any peace mission in Southern or Central Africa region will depend in no small measure on the involvement of South Africa, whose commitment of material support to the peace process may be of special importance.

\section{The challenge of burden sharing}

South Africa states in the White Paper that it will not commit itself to participating in any peace mission which is patently under-resourced and which does not have sufficient means to achieve the set mandate. ${ }^{62}$ This boils down to the point that peace missions require adequate force numbers and equipment, particularly those conducted under chapter seven of the UN Charter, where the task is to impose peace as a prerequisite for negotiations and deter hostility while talks are in progress. Military officers with peacekeeping experience are ad idem that peace missions are doomed to fail if they lack adequate personnel and technical support. In this regard, an earlier UN Department of Peacekeeping Operations study indicated that a credible peace mission in the DRC would require 100,000 well equipped troops if a peace plan was to be successful in separating the combatants. It can

\footnotetext{
60 K Annan, "The causes of conflict and the promotion of durable peace and sustainable development in Africa: Report of the Secretary-General, 1998", http.www.un.org/ecosodev/geninfo/afrec/sgreport/report.htm, 13 January 1999.

$61 \quad$ J Cilliers, "Co-option and burden sharing - a security recipe for an uncertain world?", Indicator SA, vol 16, no 2, Winter 1999, p.90.

62 White Paper on South African Participation in International Peace Missions, op cit, p.27.
} 


\section{Neethling}

therefore be questioned as to whether the relevant role-players in the region and further afield are ready to muster the forces and equipment for operations of the required magnitude on the continent. ${ }^{63}$

The current world order and the new security paradigm regarding the 'indigenising' of peacekeeping has profound implications for South Africa as a major role-player on the African continent. It must be clear that inevitable concomitant responsibilities flow from South Africa's position of economic and military strength in Southern Africa, and that the country will be drawn inexorably into shouldering a substantial contribution to future multinational peace missions in Southern Africa and further afield. In this regard, South Africa and other role-players on the continent simply have to accept greater responsibilities for engaging in acute intra-state conflicts: especially since Africa is the continent most plagued by conflict. However, Africa accounts for barely 1 per cent of the global $\mathrm{GDP}^{64}$ which implies that the continent is not comparable to Europe, where NATO as a strong and well-resourced military alliance is willing and able to play a role in peacekeeping to complement UN efforts in acute civil conflicts. The European situation is especially evident from developments in Kosovo, where the peace process draws on the support of a number of wealthy nations that are members of the European Union and NATO. It should also be realised that there is an immense gulf in equipment and training that effectively separates organisations such as NATO from regional organisations in Africa. Therefore, there is considerable substance in the observation that it seems inevitable that the unfortunate result of this will be the development of a two-tiered system of global peacekeeping - one set of standards for the developed world and another for Africa. ${ }^{65}$

Cilliers argues that " $[u]$ ntil such time as war and conflict in Africa return to more acceptable levels that 'allow' for international involvement, Africans will inevitably have to 'fend for themselves' in whatever manner they can. Indeed, they are doing precisely this in the Democratic Republic of the Congo, Congo-Brazzaville, Angola, Sudan, Niger, Ethiopia, Eritrea, Somalia, Algeria and Uganda. Co-option and burden sharing are inevitable corollaries of these trends. Until Africa finds its own security balance, however, even this support will be more symbolic than real". ${ }^{66}$ Be that as it may, one can hardly disagree with the suggestion that the Western-driven Security Council is not likely to deepen its involvement in African conflicts in the near future, notwithstanding its responsibility for the maintenance of international peace and security. ${ }^{67}$ Also, it has to be seen whether the international community will respond to calls by Secretary-General Annan for more robust UN peacekeeping against the background of recent lessons in Sierra Leone. ${ }^{68}$

Over and above, it would seem that Africa simply has to accept the necessity to develop and form regional "coalitions of the willing" to take care of its own peacekeeping requirements. But, because African states are often not in a position to respond effectively without external assistance, international and specifically Western contributions are imperative. It remains important that Africans and the international community - including the donor community - work together to improve responses to conflict management and peacekeeping in complex emergencies such as the DRC and future civil conflicts. Burden sharing would seem to be the only option and the only

63 S Laufer, "Officers tell why peacekeeping missions fail", Business Day, 26 March 1999, p.2; S. Laufer, "100 000 troops needed in Congo, says study", Business Day, 26 March 1999, p.2.

64 Anon, "Outlook for Africa bleak, says report", Business Day, 1 June 2000, p.13.

65 J Cilliers, "Regional African peacekeeping capacity - mythical construct or essential tool?", op cit, p.12.

66 Ibid.

67 EG Berman and KE Sams, op cit, p.30.

68 IRIN, "Annan explores the need for more robust peacekeeping missions", http://www.reliefweb.int/IRIN/cea/coutrystories/drc/20000531.phtml, 5 June 2000. 
responsible modus operandi, and South Africa as a regional hegemony can play an important international role in this regard.

\section{Conclusion}

As South Africa is expected to serve as an African leader in peacekeeping and especially in securing regional stability, there is a realisation on its part that it has a responsibility to consider any commitment to participation on the basis of a sound policy framework. It has therefore duly considered and addressed the conditions and criteria for involvement. It has also addressed the question of national interests within which such participation could be framed, since the political will to commit resources to peace missions will depend largely upon the perceived national interest of the contributor.

Of equal concern is the question of capacity building and training for peacekeeping. Since the government is clearly committed to shouldering its part in the conduct of peace support efforts in Africa, the SANDF has rightfully indicated its intention to address the skills, attitudes and expectations of military personnel through thorough training, study programmes and exercises. Accordingly, the SANDF is committed to dedicated peace support training in efforts to establish a pool of knowledge, expertise and skills among officers and soldiers. It can thus be concluded that the SANDF has taken up the challenge of peace missions through the training and education of its personnel.

South Africa has furthermore proved its willingness and assistance to ensure that the forces of Southern Africa can train and operate together and, with its participation in multinational training initiatives, the SANDF came closer to taking up peace support responsibilities on the African continent and in Southern Africa in particular. In view of this, the military planners in South Africa realise that the future of effective participation in peace missions in this part of the continent depends on the preparation of a viable capacity to respond to emergencies - not only in terms of preventive diplomacy, but also in terms of the timely deployment of adequate numbers of trained and equipped personnel to maximise the chances of creating or upholding peace.

It can furthermore be stated that the White Paper has impelled South Africa into a closer consideration of its position on participation in peace missions. The document clearly outlines those principles that the government believes should serve as a leitmotiv for involvement in peace missions. It must also be clear that if South Africa is to become involved in conflict situations of a peace mission nature, its involvement in such operations will require a judicious balancing of regional interests with the long-term prospects of resolving the conflict in the country concerned. Ultimately, the key question is whether both South Africa and the region can respond appropriately to the challenges in the field of peacekeeping. This will depend, critically, on the capacity of both national governments and the overarching multinational competencies to co-ordinate and implement efforts in this regard, and to muster adequate force numbers with proper technical support.

Yet, it must be clear that regional organisations can only be as effective as their members and resources. In this regard, regional approaches to peacekeeping in Africa bring little capability in sharing the burden of peacekeeping requirements on the continent. Scant economic resources simply restrict their capacity. Thus the thrust towards the provision of regional peacekeeping forces may not mean any abandonment of African organisations to their own devices and means. Moreover, the fact remains that the UN is still the pre-eminent international authority with the responsibility for dealing with international peace and security. 


\section{Neethling}

However, African role-players have to take cognisance of the fact that the UN is currently not ready to deploy robust force postures that are able to conduct peace enforcement operations in acute conflicts in Africa. To this end, African organisations are increasingly intent on engaging in and dealing with their own conflicts and they need to place a high premium on staffing institutional structures concerned with conflict-resolution and peacekeeping. This does not imply that Africans should simply content themselves with the trend concerning the development of a two-tiered system of global peacekeeping with one set of standards for the developed world and another for Africa. African role-players need to constantly mobilise the international community with a view to ensuring that international policies and practices contribute meaningfully to peace and stability in Africa. It is imperative that the UN will rethink the need for more robust peacekeeping in view of recent lessons in Sierra Leone. Yet, Africans should also be mindful of the point that until wars and conflict in Africa return to "more acceptable levels" it is unlikely that appeals for greater international assistance will result in substantially greater proportions of international involvement in stabilising African conflicts.

Looking forward, it seems that South Africa is compelled to play an active political-military role in resolving current and future conflicts in the region. But, despite the sophisticated nature of its policy guidelines for participation in peace missions, the decision-makers and role-players concerned with peace-keeping may soon discover that South Africa is entering the peace support domain at a time when "polite peacekeeping" is over and one can indeed expect that major challenges will face South Africa in this regard. 